\title{
Genome-wide association study applied to type traits related to milk yield in water buffaloes (Bubalus bubalis)
}

\author{
Jessica Lorena Gonzalez Guzman, ${ }^{1}$ Sirlene Fernandes Lázaro, ${ }^{1}$ André Vieira do Nascimento, ${ }^{1}$ \\ Daniel Jordan de Abreu Santos, ${ }^{2}$ Diercles Francisco Cardoso, ${ }^{1}$ Daiane Cristina Becker Scalez, ${ }^{1}$ \\ Lúcia Galvão de Albuquerque, ${ }^{1}$ Naudin Alejandro Hurtado Lugo, ${ }^{1}$ and Humberto Tonhati ${ }^{1 *}$ \\ ${ }^{1}$ Departamento de Zootecnia, Faculdade de Ciências Agrárias e Veterinárias, Universidade Estadual Paulista, Jaboticabal, São Paulo 14884-900, \\ Brazil \\ ${ }^{2}$ Department of Animal Sciences, University of Maryland, College Park 20742
}

\section{ABSTRACT}

This research aimed to estimate genetic parameters for milk yield and type traits [withers height (WH), croup height $(\mathrm{CH})$, body length (BL), croup length (CL), iliac width (ILW), ischial width (ISW), and thoracic circumference] in Murrah buffaloes and to identify genomic regions related to type traits by applying a single-step genome-wide association study. Data used to estimate the genetic parameters consisted of 601 records of milk yield in the first lactation and the aforementioned type traits. For the single-step genome-wide association study, 322 samples genotyped with a $90 \mathrm{~K}$ Axiom Buffalo Genotyping array (Thermo Fisher Scientific, Santa Clara, CA) were used. Bivariate analysis revealed that heritability for milk yield $(\mathrm{kg})$ at $305 \mathrm{~d}$ was $0.31 \pm 0.11$, whereas it ranged from $0.22 \pm 0.07$ to $0.34 \pm 0.09$ for the studied conformation traits. Based on the percentages of genetic variance explained by windows of 10 markers, there were 16 genomic regions explaining more than $0.5 \%$ of the variance for $\mathrm{WH}$, $\mathrm{CH}, \mathrm{BL}, \mathrm{CL}, \mathrm{ILW}$, ISW, and thoracic circumference. Between those regions, 4 were associated with more than 1 trait, suggesting pleiotropic roles for some genes of Bos taurus autosome (BTA) 12 on CL and WH, BTA13 on ISW and ILW, BTA23 on $\mathrm{CH}$ and BL, and BTA2 8 on ISW and BL. Most of these regions coincide with known quantitative trait loci for milk traits. Thus, further studies based on sequence data will help to validate the association of this region with type traits and likely identify the causal mutations.

Key words: conformation trait, SNP marker, protein, explained variance

\footnotetext{
Received February 15, 2019.

Accepted October 7, 2019.

*Corresponding author: humberto.tonhati@fcav.unesp.br
}

\section{INTRODUCTION}

In addition to being socioeconomically relevant in Asian countries as a workforce in rice plantations, buffaloes (Bubalus bubalis) are a good food source. In particular, their milk has high levels of fat, protein, and TS, which elevate the yield of dairy products (Warriach et al., 2015; Liu et al., 2018). Milk's physicochemical composition and functional properties provide highquality milk derivatives such as mozzarella cheese, yogurt, and other by-products (Michelizzi et al., 2010).

Even though buffaloes have been recently introduced in Brazil, the country currently has about 1,381,395 buffaloes (FAO, 2017), which is the largest buffalo herd outside the Asian continent. The herd is formed by the Murrah and Jafarabadi breeds of Indian origin, the Mediterranean breed from Italy, and their cross-breed. This herd has been increasing in number and productivity, allowing the development of genetic evaluation and selection programs, thus making Brazilian producers exporters of genetic material to South American countries especially. The main selection criterion has been milk yield (kilograms of milk per lactation) without considering other important traits from an economic point of view, such as fat and protein yield and fat and protein percentages.

Among the morphological indicators of milk yield and especially longevity, type traits can help in the selection of animals through a correlated response (Cole et al., 2011; Ma et al., 2012). Therefore, type traits have become part of the selection objectives of some cattle breeding programs because they reduce the number of animals replaced and, consequently, increase production while guaranteeing herd longevity (Cruickshank et al., 2002; Formigoni et al., 2005; Lagrotta et al., 2010; Sewalem et al., 2010).

Genome-wide association study (GWAS) identifies regions in the genome that are associated with phenotypes of interest (Ma et al., 2012), making it pos- 
Table 1. Descriptive statistics for accumulated milk yield at $305 \mathrm{~d}$ (MY) and type traits

\begin{tabular}{lrrrrr}
\hline Trait & \multicolumn{1}{c}{ Mean } & SD & Maximum & Minimum & No. of records \\
\hline MY $(\mathrm{kg})$ & $2,190.00$ & 46.79 & $4,170.00$ & 0.00 & 601 \\
Withers height $(\mathrm{cm})$ & 133.40 & 11.55 & 147.00 & 116.00 & 601 \\
Croup height $(\mathrm{cm})$ & 135.80 & 11.65 & 147.00 & 123.00 & 601 \\
Body length $(\mathrm{cm})$ & 117.84 & 10.85 & 145.07 & 85.88 & 601 \\
Croup length $(\mathrm{cm})$ & 42.37 & 6.51 & 59.00 & 31.00 & 601 \\
Iliac width $(\mathrm{cm})$ & 55.56 & 7.45 & 74.00 & 37.00 & 601 \\
Ischial width $(\mathrm{cm})$ & 26.51 & 5.14 & 39.00 & 15.00 & 601 \\
Thoracic circumference $(\mathrm{cm})$ & 224.90 & 15.00 & 277.00 & 170.00 & 601 \\
\hline
\end{tabular}

sible to identify genes that have an important effect on such phenotypes of interest (Hirschhorn and Daly, 2005; Frazer et al., 2009). The single-step GWAS (ssGWAS), proposed by Wang et al. (2012), combines all genotypic and phenotypic information available from animals in a single step and then converts estimated breeding values to marker effects and weights. As a result of the ssGWAS, the identified genomic regions help explain the physiological processes and biological traits of economic interest. Such genes could then be used as candidates to search for possible causal mutations, and the markers could be implemented in future genomic evaluations (Peters et al., 2012).

To the extent of our knowledge, GWAS for buffalo are mainly focused on milk traits and are limited to a few studies, such as in Chinese Murrah buffalo (Deng et al., 2019), Egyptian buffalo (El-Halawany et al., 2017), and Brazilian Murrah buffalo (de Camargo et al., 2015). There is a lack of studies on different traits that can be related to milk production, such as type traits. Thus, this study aimed to estimate genetic parameters for milk yield and type traits - withers height (WH), croup height $(\mathbf{C H})$, body length (BL), croup length (CL), iliac width (ILW), ischial width (ISW), and thoracic circumference (TC) - in Murrah buffaloes. In addition, we aimed to identify, using the ssGWAS procedure, genomic regions and genes that are possibly related to type traits.

\section{MATERIALS AND METHODS}

\section{Phenotypic Data}

This study used the phenotypic data of 601 Murrah buffaloes from a Brazilian herd located in the state of Rio Grande do Norte. The analyzed traits were milk yield (MY; $\mathrm{kg}$ ) accumulated at $305 \mathrm{~d}$ and the type traits WH, CH, BL, CL, ILW, ISW, and TC.

The analyzed data comprised measures of first-lactation females born between 2000 and 2017. The 34 contemporary groups (average $=18$ animals/group; range
$=3-61$ animals/group) consisted of a combination of herd, year, and calving season (October-March and April-September) so that each contemporary group contained a minimum of 3 animals and the trait records were within \pm 3 standard deviations of the group mean. The descriptive statistics of the data are shown in Table 1.

\section{Variance Component Estimation}

Components of variance of MY and type traits were estimated by Gibbs sampling using the GIBBS2F90 program (Misztal, 2007) under a bivariate model that included contemporary group, direct additive genetic and residual effects, and buffalo age at first calving (linear and quadratic) as a covariate. The total number of animals in the pedigree was 20,092. The model adopted, represented in matrix notation, was

$$
\mathbf{y}=\mathbf{X} \boldsymbol{\beta}+\mathbf{Z a}+\mathbf{e},
$$

where $\mathbf{y}$ is the vector of observed traits, $\boldsymbol{\beta}$ is the vector of systematic effects, $\mathbf{a}$ is the vector of additive genetic random effects, and $\mathbf{e}$ is the vector of residual random effects. The $\mathbf{X}$ and $\mathbf{Z}$ are the incidence matrices corresponding to systematic and additive genetic random effects, respectively.

Uniform a priori distribution was defined for systematic effects $(\boldsymbol{\beta})$. Gaussian and inverted Wishart distributions were defined as a priori distributions for random effects and (co)variance components, respectively:

$$
\begin{aligned}
& \boldsymbol{\beta} \propto \text { constant; } \\
& a \mid \mathbf{G} \sim \operatorname{MVN}[0,(\mathbf{G} \otimes \mathbf{H})] ; \\
& \mathbf{G} \mid S_{g}, v_{g} \sim I W\left(S_{g} v_{g}, v_{g}\right) ; \\
& \mathbf{R} \mid S_{r}, v_{r} \sim I W\left(S_{r} v_{r}, v_{r}\right) ;
\end{aligned}
$$

where $a$ is the vector of additive genetic random effects; $\mathbf{G}$ and $\mathbf{R}$ are the matrices of (co)variances of additive 
genetic and residual effects, respectively; $\mathbf{H}$ is the matrix that combines the pedigree and the genomic-based relationship matrices; $\boldsymbol{\beta}$ is a diagonal known matrix with values $1 \mathrm{e}+10$ (large variances) that represent vague prior knowledge for systematic effects; $\otimes$ is the Kronecker product; and $S_{g}$ and $v_{g}$ and $S_{r}$ and $v_{r}$ are the values of a priori and degrees of freedom for additive genetic and residual (co)variances, respectively.

Gibbs sampling was used to generate random samples of the posterior distribution by successive samples of the conditional distributions of the model elements. In each bivariate analysis, a chain with 750,000 samples was generated so that the first 150,000 were discarded. The values were saved with a sampling interval (thin) of 50 iterations so that the autocorrelation values were sufficient to consider the samples as independent. These values were defined by preliminary analyses in which the convergence and the distribution of the samples were evaluated using graphical inspection and $\mathrm{R}$ package BOA (Smith, 2007). For all analyses, convergence was assessed using the methodology presented by Heidelberger and Welch (1983).

\section{Genotyping}

Genomic DNA purification was done from either blood or tail hair follicles following respective protocols of the NucleoSpin Tissue extraction kit (MachereyNagel, Düren, Germany). The animals were genotyped using the 90K Axiom Buffalo SNP Array (Thermo Fisher Scientific, Santa Clara, CA). Quality control of genotyping data was performed with Plink software version 1.9 (Chang et al., 2015). The following exclusion criteria were applied for quality control of SNP: minor allele frequency $<0.05$, call rate $<0.95, P$-value for Hardy-Weinberg equilibrium $<10^{-6}$, and elimination of duplicated SNP. The criterion for exclusion of the sample was a call rate $<0.90$. After application of quality control, 49,010 autosomal markers and 322 animals were left. The imputation of missing markers was performed using Beagle software version 5.0 (Browning and Browning, 2016).

\section{ssGWAS}

For the prediction of the genomic breeding values, we used BLUPF90 software (Misztal et al., 2002), applying a single-trait animal model. The general model used for the traits can be described as in Equation 1.

The combination of the additive relationship matrix (A) with the genomic relationship matrix $(\mathbf{G})$ gave rise to a new matrix, $\mathbf{H}^{-1}$ (Aguilar et al., 2010):

$$
\mathbf{H}^{-1}=\mathbf{A}^{-1}+\left[\begin{array}{cc}
0 & 0 \\
0 & \mathbf{G}^{-1}-\mathbf{A}_{22}^{-1}
\end{array}\right],
$$

where $\mathbf{A}^{-1}, \mathbf{G}^{-1}$, and $\mathbf{A}_{22}^{-1}$ are the inverse of the relationship matrix based on pedigree information, the inverse of the genomic relationship matrix, and the inverse of the relationship matrix based on pedigree information of genotyped animals, respectively.

The genomic relationship matrix was obtained according to VanRaden (2008):

$$
\mathbf{G}=\frac{\mathbf{Z Z}^{\prime}}{2 \sum_{j=1}^{m} p_{j}(1-p)}
$$

where $\mathbf{Z}$ is $\mathbf{M}-\mathbf{P}$, in which $\mathbf{M}$ is the genotype matrix with markers in the columns and animals in the rows, $m$ is the number of markers, and $\mathbf{P}$ is the frequency matrix of the second allele $p_{j}$, expressed as $2 p_{j}$.

The effects of the SNP were obtained from the genomic breeding values of the genotyped animals iteratively using the postGSf90 software of the BLUPF90 family (Misztal et al., 2002) followed by the preGSf90 and BLUPF90 software, where postGSf90 calculates each SNP effect, using different weights in the genomic relationship matrix as described by Wang et al. (2012), therefore allowing different weights for the SNP. The SNP effects were calculated following the equation

$$
\hat{\mathbf{u}}=\mathbf{D} \mathbf{Z}^{\prime}[\mathbf{Z D Z}]^{-1} \hat{\mathbf{a}}_{\mathbf{g}}
$$

where $\hat{\mathbf{u}}$ is the vector of SNP effects, $\mathbf{D}$ is the diagonal matrix containing weights for the effect of SNP, $\mathbf{Z}$ is a matrix that relates genotypes of each locus, and $\hat{\mathbf{a}}_{\mathbf{g}}$ is the vector of predicted values for the genotyped animals.

In this study, 2 iterations were performed to estimate the SNP effect. In the first, the weights for SNP effects were assumed equal to 1 , which were then calculated as a function of the square of the markers effects and allele frequency effects and used in the second iteration. According to Wang et al. (2014), the weighing is important for evidencing the regions affecting a given trait the most by attributing a higher or lower weight to the SNP, accordingly.

The weight of each SNP was calculated by multiplying the squared effect of the SNP $i\left(\hat{\mathbf{u}}_{i}{ }^{2}\right)$ by $2 p_{i} q_{i}$, where $p_{i}$ is the frequency of the second allele of the SNP $i$ and $q_{i}$ is $\left(1-p_{i}\right.$; Zhang et al., 2010). The percentage of genetic variance explained by each marker was calculated following the equation 


$$
\frac{2 \sum_{k=1}^{n}\left(p_{n} q_{n}\right) \hat{\mathbf{u}}_{n}^{2}}{2 \sum_{k=1}^{n}\left(p_{k} q_{k}\right) \hat{\mathbf{u}}_{k}^{2}}
$$

where $n$ is the total number of loci and $k$ is the $k$ th marker performed using the BLUPF90 software family (Misztal et al., 2002). The results of the ssGWAS were presented based on nonoverlapping windows of 10 adjacent SNP, following Tiezzi et al. (2015) and Sun et al. (2011). Windows accounting for more than $0.5 \%$ of genetic variance (Fragomeni et al., 2014) were treated as significant regions.

\section{Genes and QTL Prospecting}

The ssGWAS analysis used a Buffalo-specific array of SNP positions based on the bovine genome. The genes mapped in $500 \mathrm{~kb}$ up- or downstream of the significant windows were assessed in the Ensembl Genome Browser (http://www.ensembl.org/index.html) using the BioMart tool version 93 (Kinsella et al., 2011). The 500-kb distance was used to capture regulatory and functional regions that were close to the genes but not necessarily contained in them (Peñagaricano et al., 2013). We verified the existence of QTL already described in a particular genomic region using the CattleQTLdb tool version 35 (National Animal Genome Research Program, 2018). Both prospective analyses were based on the UMD version 3.1 assembly of the bovine genome (Zimin et al., 2009).

\section{RESULTS AND DISCUSSION}

\section{Estimated Genetic Parameters}

The MY average $(2,190 \mathrm{~kg})$ for animals in a twicedaily milking system was higher than the averages of 1,496 and $1,650 \mathrm{~kg}$ reported for Murrah buffaloes in the same milking frequency by Tonhati et al. (2000a,b). This difference indicates productivity progress, most likely achieved due to management improvement and effective selection for this trait.

The estimates of heritability for the studied traits were higher than $0.22 \pm 0.07$, indicating that a considerable part of the variation of the respective traits resulted from the additive effect (Table 2). The heritability of the type traits ranged from $0.22 \pm 0.07$ (ILW) to $0.34 \pm 0.09(\mathrm{CH})$.

In this study, the estimate of heritability for MY was $0.31 \pm 0.11$, similar to the values found by Borquis et al. (2013) for test-day milk yield in multitrait random regression analyses, with estimates ranging from 0.23 to 0.38. However, Tonhati et al. (2000a) and El-Halawany et al. (2017) reported heritability values for MY ranging from $0.21 \pm 0.32$ and 0.2433 , respectively, in Egyptian, Brazilian, and water buffaloes, which are lower than those found in this study. On the other hand, Liu et al. (2018) found similar heritability values in Italian Mediterranean buffaloes (0.33).

In general, estimates of heritability for type traits (Table 2) were similar to those previously reported in cattle. For instance, Wenceslau et al. (2000) reported similar values for $\mathrm{CH}(0.37)$ and $\mathrm{TC}(0.23)$ in dairy cattle. In addition, estimates of heritability for CL (0.33 \pm $0.10)$ and $\mathrm{WH}(0.34 \pm 0.02$ and $0.35 \pm 0.03)$ were simi-

Table 2. Posterior means, with standard deviation (in parentheses) and highest posterior density region (95\%) heritability (in square brackets), variance components, and additive genetic and phenotypic correlations for the 7 type traits and accumulated milk yield at 305 d (MY), obtained

\begin{tabular}{|c|c|c|c|c|c|c|}
\hline Trait & $\sigma_{a(\mathrm{MY})}^{2}$ & $\sigma_{a}^{2}$ & $\mathrm{~h}_{1}^{2}$ & $\mathrm{~h}_{2}^{2}$ & $\mathrm{r}_{\mathrm{g} 1,2}$ & $\mathrm{r}_{\mathrm{p} 1,2}$ \\
\hline \multirow[t]{2}{*}{$\mathrm{MY}-\mathrm{WH}$} & $136,928.90(53,988.26)$ & $5.03(1.39)$ & $0.31(0.11)$ & $0.33(0.08)$ & $0.041(0.241)$ & $0.100(0.177)$ \\
\hline & {$[41,500 ; 245,500]$} & {$[2.35 ; 7.74]$} & {$[0.10 ; 0.53]$} & {$[0.17 ; 0.49]$} & {$[-0.438 ; 0.498]$} & {$[-0.258 ; 0.440]$} \\
\hline \multirow[t]{2}{*}{ MY-CH } & $135,662.90(53,857.46)$ & $4.48(1.27)$ & $0.31(0.11)$ & $0.34(0.09)$ & $0.228(0.247)$ & $0.259(0.182)$ \\
\hline & {$[40,570 ; 246,400]$} & {$[2.03 ; 6.96]$} & {$[0.11 ; 0.53]$} & {$[0.18 ; 0.52]$} & {$[-0.251 ; 0.720]$} & {$[-0.113 ; 0.605]^{\prime}$} \\
\hline \multirow[t]{2}{*}{ MY-BL } & $137,436.20(54,150.74)$ & $10.29(3.43)$ & $0.31(0.11)$ & $0.26(0.08)$ & $-0.015(0.273)$ & $-0.024(0.209)$ \\
\hline & {$[41,660 ; 246,700]$} & {$[3.95 ; 17.12]$} & {$[0.10 ; 0.53]$} & {$[0.11 ; 0.43]$} & {$[-0.552 ; 0.513]$} & {$[-0.455 ; 0.367]$} \\
\hline \multirow[t]{2}{*}{ MY-CL } & $138,712.50(53,995.93)$ & $2.03(0.65)$ & $0.31(0.11)$ & $0.31(0.09)$ & $0.168(0.263)$ & $0.163(0.193)$ \\
\hline & {$[43,550 ; 248,000]$} & {$[0.74 ; 3.30]$} & {$[0.11 ; 0.53]$} & {$[0.13 ; 0.49]$} & {$[-0.350 ; 0.671]$} & {$[-0.227 ; 0.535]$} \\
\hline \multirow[t]{2}{*}{ MY-ILW } & $137,545.30(54,143.03)$ & $3.10(1.02)$ & $0.31(0.11)$ & $0.22(0.07)$ & $0.046(0.264)$ & $0.063(0.209)$ \\
\hline & {$[42,289 ; 248,400]$} & {$[1.17 ; 5.07]$} & {$[0.11 ; 0.53]$} & {$[0.09 ; 0.36]$} & {$[-0.473 ; 0.555]^{\prime}$} & {$[-0.354 ; 0.462]$} \\
\hline \multirow[t]{2}{*}{ MY-ISW } & $133,804.30(54,424.99)$ & $1.91(0.58)$ & $0.31(0.11)$ & $0.31(0.08)$ & $-0.278(0.258)$ & $-0.115(0.198)$ \\
\hline & {$[36,970 ; 243,600]$} & {$[0.82 ; 3.05]$} & {$[0.10 ; 0.53]$} & {$[0.14 ; 0.47]$} & {$[-0.774 ; 0.220]$} & {$[-0.509 ; 0.263]$} \\
\hline \multirow[t]{2}{*}{ MY-TC } & $138,819.20(54,075.46)$ & $43.54(15.00)$ & $0.31(0.11)$ & $0.29(0.09)$ & $-0.270(0.272)$ & $-0.183(0.205)$ \\
\hline & {$[43,700 ; 249,000]$} & {$[15.59 ; 72.44]$} & {$[0.11 ; 0.54]$} & {$[0.11 ; 0.47]$} & {$[-0.778 ; 0.284]$} & {$[-0.577 ; 0.236]$} \\
\hline
\end{tabular}
for Murrah buffaloes from bivariate models ${ }^{1}$

${ }^{1} \sigma_{a(\mathrm{MY})}^{2}=$ additive genetic variance for $\mathrm{MY} ; \sigma_{a}^{2}=$ additive genetic variance for the type traits (WH $=$ withers height; $\mathrm{CH}=$ croup height; BL $=$ body length; $\mathrm{CL}=$ croup length; ILW = iliac width; $\mathrm{ISW}=$ ischial width; $\mathrm{TC}=$ thoracic circumference); $\mathrm{h}_{1}^{2}=\mathrm{heritability} \mathrm{for} \mathrm{MY} ; \mathrm{h}_{2}^{2}=$ heritability for the type traits; $\mathrm{r}_{\mathrm{g} 1,2}=$ genetic correlation between MY and type traits; $\mathrm{r}_{\mathrm{p} 1,2}=$ phenotypic correlation between MY and type traits. 
lar to those previously reported in cattle (Hagger and Hofer, 1991; Cyrillo et al., 2001). However, Verneque et al. (2008) found higher heritabilities for $\mathrm{CH}(0.60 \pm$ $0.04)$ and $\mathrm{TC}(0.31 \pm 0.04)$.

The ILW had the lowest estimate of heritability $(0.22 \pm 0.07)$ in the current study, which agrees with the value presented by Verneque et al. (2008) in dairy cattle and Cyrillo et al. (2001) in beef cattle, indicating the importance of the variation attributed to the environment and nonadditive genetic effects on this trait. Regarding the BL, the estimate was higher than the estimates reported in dairy cattle (Wenceslau et al., 2000; Verneque et al., 2008) but smaller than those found in beef cattle (Cyrillo et al., 2001). For ISW, the estimate of heritability was greater than previous reports for dairy cattle (Verneque et al., 2008) and beef cattle (Cyrillo et al., 2001). The different estimates may be attributed to differences between the species, either biological or in the management system to which they are submitted.

Genetic correlations between type traits and MY ranged between -0.278 and 0.228 (Table 2) and were mostly of low magnitude, which may indicate that only some genes act on both traits. Some traits, such as WH, BL, and ILW, presented almost a null correlation with MY, suggesting that selection for one trait will not cause a correlated gain in the other. On the other hand, $\mathrm{CH}$ and $\mathrm{CL}$ were positively correlated with MY, although of moderate magnitude, meaning that selection to increase these traits can affect MY. Meanwhile, ISW and TC were negatively correlated with MY, meaning that selecting for MY will reduce ISW and TC.

In summary, we found mostly low correlations between MY and the type traits; that is, it would take a long time to observe an actual effect on MY if using these traits as selection criteria to select for MY. However, further investigation involving larger populations is still required, especially due to contrary postulations in cattle studies. For instance, Wenceslau et al. (2000) studied Gir dairy cattle and found negative genetic correlations between milk yield and these type traits, concluding that selection for MY would cause the cow's overall size to decrease as a correlated response.

Although we observed correlations ranging from low to medium magnitude with milk yield in buffaloes, type traits are associated with handling and productive longevity. Future studies can be carried out to correlate longevity with linear traits to highlight their importance in the species.

\section{GWAS}

Figure 1 shows, for each type trait, that the Manhattan plots of genetic variance accounted for the nonoverlap- ping windows of 10 adjacent SNP. In total, 16 genomic regions presented windows explaining more than $0.5 \%$ of genetic variance for 1 of the 7 analyzed type traits (Table 3), being that 4 of these regions were shared by 2 traits. A genomic region of BTA12 showed an association with CL and WH, BTA13 showed an association with ISW and ILW, BTA23 showed an association with $\mathrm{CH}$ and BL, and BTA28 showed an association with ISW and BL. All the type traits presented at least 1 significant region overlapping with known QTL for MY and milk constituents reported in buffaloes or cattle, emphasizing the existence of genes in the same region that could be coaffecting productive and morphological traits, responsible for the observed genetic correlation between them. The full list of known QTL overlapped by those regions can be found in Supplemental Tables S1 to S7 (https://doi.org/10.3168/jds.2019-16499).

An overlapping region between BL and ILW that explains a high proportion of genetic variance was detected in BTA4 near the $44 \mathrm{Mb}$. Studies in beef cattle suggest that this region is a QTL of body development (Snelling et al., 2010) and maternal performance traits, such as milk yield (Michenet et al., 2016). In addition, the gene $C C D C 146$, mapped in this region, was an upregulated gene in the mammary gland of Jersey cattle during the early stage of lactation (Bhat et al., 2019). A further region significantly associated with 2 of the studied traits was revealed at BTA23, from 24.6 to $25.6 \mathrm{Mb}$ for BL and CH. Mokhber et al. (2018) compared dairy breeds of different body sizes and productivity and identified a selection signature in buffaloes in this same region. In dairy cattle, it was previously associated with carcass conformation score (Mao et al., 2016), suggesting its association with body development and morphological traits. Additionally, this region assembles several genes, such as ELOVL5, TMEM14A, and FBXO9, participating in distinct metabolic processes, such as immunity, growth, and reproduction, and may affect other traits, including milk traits (Bennewitz et al., 2003).

A rich gene region between 52.7 and $53.7 \mathrm{Mb}$ in the BTA7 explained a high proportion of the variance in TC and overlap to known QTL of morphological traits in dairy cattle, such as udder attachment and chest width (Cole et al., 2011). The HBEGF gene corresponds to a potential candidate for body development in this region, as its knockout resulted in reduced body size in mice (Yamazaki et al., 2003). In addition, the $C D 14$ gene that is a transmembrane receptor also mapped in this window was previously tagged as a candidate gene to MY and fat and protein yield in cattle (Cochran et al., 2013). The genomic region of BTA8 showing windows that explain a high proportion of genetic variance of $\mathrm{CH}$ encompasses the gene PTK2B (ENSBTAG00000005958), which plays a key role in 

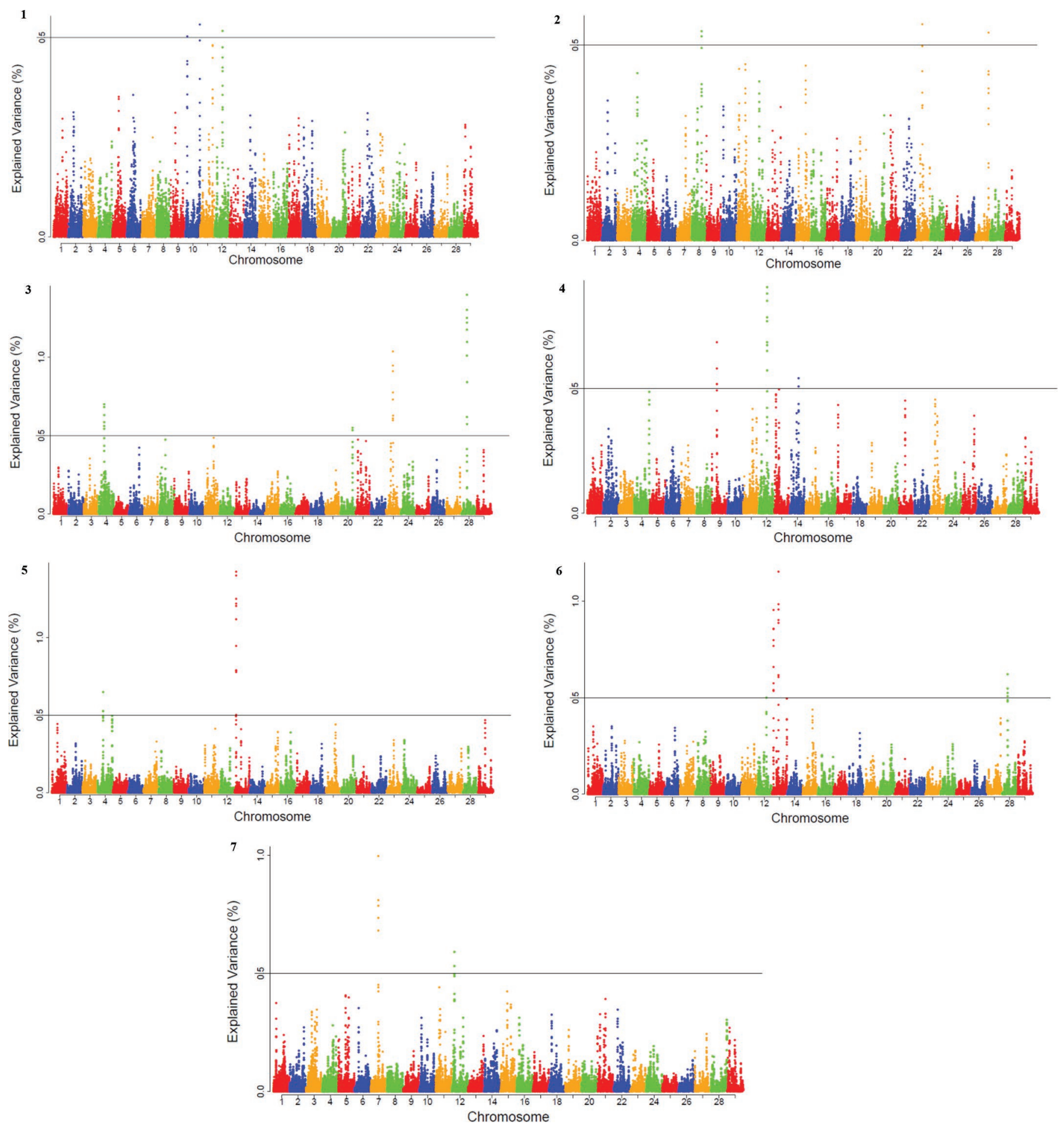

Figure 1. Manhattan plots for withers height (1), croup height (2), body length (3), croup length (4), iliac width (5), ischial width (6), and thoracic circumference (7) traits in buffaloes. The chromosomes from 1 to 29 are shown separated by alternating colors. The horizontal line indicates the highest percentage of variance explained by the windows of 10 adjacent SNP for the trait. On the x-asis are the physical positions of SNP by chromosome, separated by colors, based on the Bos taurus UMD 3.1 genome assembly (Zimin et al., 2009). 
Table 3. Genes for type traits in buffaloes, their positions in base pairs (bp) in cattle chromosome (chr), and descriptions based on windows of 10 adjacent SNP explaining at least $0.5 \%$ of the trait genetic variance

\begin{tabular}{|c|c|c|c|c|}
\hline \multirow[b]{2}{*}{$\mathrm{Chr}$} & \multicolumn{2}{|c|}{ Position (bp) } & \multirow[b]{2}{*}{ Trait } & \multirow[b]{2}{*}{ Genes } \\
\hline & Start & End & & \\
\hline 4 & $43,697,844$ & $44,697,844$ & Body length & $\begin{array}{l}\text { PTPN12, CCDC146, FGL2, ARMC10, NAPEPLD, FAM185A, } \\
\text { RSBN1L, FBXL13, GSAP, LRRC17 }\end{array}$ \\
\hline 7 & $52,707,065$ & $53,707,065$ & Thoracic circumference & $\begin{array}{l}\text { PSD2, SRA1, APBB3, ZMAT2, PURA, NRG2, EIF 4EBP3, } \\
\text { CD14, IK, NDUFA2, WDR55, PCDHA6, CYSTM1, PFDN1, } \\
\text { DND1, HARS, HBEGF, SLC4A9, HARS2, IGIP, PCDHA13, } \\
\text { SLC35A4, TMCO6, PCDHA3, PCDHA11 }\end{array}$ \\
\hline 8 & $75,172,334$ & $76,172,334$ & Croup height & $\begin{array}{l}\text { CHRNA2, PTK2B, TRIM35, APTX, EPHX2, DNAJA1, } \\
\text { STMN4, SMU1, GULO, ADRA1A }\end{array}$ \\
\hline 9 & $33,388,542$ & $34,388,542$ & Croup length & $\begin{array}{l}\text { RFX6, ZUP1, GOPC, KPNA5, FAM162B, NEPN, VGLL2, } \\
\text { DCBLD1, ROS1 }\end{array}$ \\
\hline 10 & $12,672,069$ & $13,672,069$ & Withers height & $\begin{array}{l}\text { DIS3L, TIPIN, SMAD6, SNAPC5, RPL4, ZWILCH, LCTL, } \\
\text { RAB11A, MAP2K1, MEGF11 }\end{array}$ \\
\hline 13 & $36,182,451$ & $37,182,451$ & Ischial width & $A R M C 4, B A M B I, M K X, M P P 7, W A C$ \\
\hline 14 & $46,893,638$ & $47,893,638$ & Croup length & NOV, TNFRSF11B, MAL2, COLEC10, SAMD12 \\
\hline 20 & $56,862,316$ & $57,862,316$ & Body length & FBXL7, MARCH11 \\
\hline 23 & $24,637,229$ & $25,637,229$ & $\begin{array}{l}\text { Croup height, body } \\
\text { length }\end{array}$ & $\begin{array}{l}\text { ELOVL5, GSTA4, TMEM14A, GSTA2, GCM1, TRAM2, } \\
\text { BOLA-DQA2, BOLA-DRA, FBXO9, ICK, BOLA-DQB, GSTA3, } \\
\text { BTNL2, GSTA5, BOLA-DQA5 }\end{array}$ \\
\hline 27 & $41,201,378$ & $42,201,378$ & Croup height & NKIRAS1, THRB, NR1D2, RPL15 \\
\hline 28 & $16,435,360$ & $17,435,360$ & $\begin{array}{l}\text { Ischial width, body } \\
\text { length }\end{array}$ & CDK1, TMEM26, RHOBTB1 \\
\hline
\end{tabular}

bone formation (Buckbinder et al., 2007) and may influence animal height. Studies with Holstein-Friesian cattle have signaled this gene as a candidate for MY, protein yield, and calving difficulty (Meredith et al., 2012; Zaborski et al., 2016).

\section{CONCLUSIONS}

The heritability estimates of the studied traits were moderate, indicating that there is enough genetic variation to achieve genetic progress in the population. The ssGWAS highlighted 19 genomic regions that were putatively related to the type traits, with a representative level of overlapping with known QTL for MY, fat and protein yields $(\mathrm{kg})$, and milk fat and protein percentages in Murrah buffaloes. A particularly interesting region detected here was BTA23 because it has been previously detected as a buffalo selection signature putatively related to body size. Thus, further studies based on sequence data will help validate the association of this region with type traits and likely identify the causal mutations.

\section{ACKNOWLEDGMENTS}

We are grateful to the following Brazilian foundations: Coordenação de Aperfeiçoamento de Pessoal de Nível Superior (CAPES, Brasília), Conselho Nacional de Desenvolvimento Científico e Tecnológico (CNPq, Brasília), Fundação de Amparo à Pesquisa do Estado de São Paulo (FAPESP, São Paulo) for grant no. 2016/21213-0, and Instituto de Ciências e Tecnologia de Ciência Animal (INCT-CA, Viçosa) for supporting this study.

\section{REFERENCES}

Aguilar, I., I. Misztal, D. L. Johnson, A. Legarra, S. Tsuruta, and T. J. Lawlor. 2010. Hot topic: A unified approach to utilize phenotypic, full pedigree, and genomic information for genetic evaluation of Holstein final score. J. Dairy Sci. 93:743-752. https://doi.org/10 $.3168 /$ jds.2009-2730.

Bennewitz, J., N. Reinsch, C. Grohs, H. Levéziel, A. Malafosse, H. Thomsen, N. Xu, C. Looft, C. Kühn, G. A. Brockmann, M. Schwerin, C. Weimann, S. Hiendleder, G. Erhardt, I. Medjugorac, I. Russ, M. Förster, B. Brenig, F. Reinhardt, R. Reents, G. Averdunk, J. Blümel, D. Boichard, and E. Kalm. 2003. Combined analysis of data from two granddaughter designs: A simple strategy for QTL confirmation and increasing experimental power in dairy 
cattle. Genet. Sel. Evol. 35:319-338. https://doi.org/10.1051/gse: 2003011.

Bhat, S. A., S. M. Ahmad, E. M. Ibeagha-Awemu, B. A. Bhat, M. A. Dar, P. T. Mumtaz, R. A. Shah, and N. A. Ganai. 2019. Comparative transcriptome analysis of mammary epithelial cells at different stages of lactation reveals wide differences in gene expression and pathways regulating milk synthesis between Jersey and Kashmiri cattle. PLoS One 14:e0211773. https://doi.org/10.1371/journal .pone.0211773.

Borquis, R. R., F. R. Neto, F. Baldi, N. Hurtado-Lugo, G. M. F. de Camargo, M. Muñoz-Berrocal, and H. Tonhati. 2013. Multipletrait random regression models for the estimation of genetic parameters for milk, fat, and protein yield in buffaloes. J. Dairy Sci. 96:5923-5932. https://doi.org/10.3168/jds.2012-6023.

Browning, B. L., and S. R. Browning. 2016. Genotype imputation with millions of reference samples. Am. J. Hum. Genet. 98:116-126. https://doi.org/10.1016/j.ajhg.2015.11.020.

Buckbinder, L., D. T. Crawford, H. Qi, H. Z. Ke, L. M. Olson, K. R. Long, P. C. Bonnette, A. P. Baumann, J. E. Hambor, W. A. Grasser, L. C. Pan, T. A. Owen, M. J. Luzzio, C. A. Hulford, D. F. Gebhard, V. M. Paralkar, H. A. Simmons, J. C. Kath, W. G. Roberts, S. L. Smock, A. Guzman-Perez, T. A. Brown, and M. Li. 2007. Proline-rich tyrosine kinase 2 regulates osteoprogenitor cells and bone formation, and offers an anabolic treatment approach for osteoporosis. Proc. Natl. Acad. Sci. USA 104:10619-10624. https: //doi.org/10.1073/pnas.0701421104.

Chang, C. C., C. C. Chow, L. C. Tellier, S. Vattikuti, S. M. Purcell, and J. J. Lee. 2015. Second-generation PLINK: Rising to the challenge of larger and richer datasets. Gigascience 4:7. https://doi .org/10.1186/s13742-015-0047-8.

Cochran, S. D., J. B. Cole, D. J. Null, and P. J. Hansen. 2013. Discovery of single nucleotide polymorphisms in candidate genes associated with fertility and production traits in Holstein cattle. BMC Genet. 14:49. https://doi.org/10.1186/1471-2156-14-49.

Cole, J. B., G. R. Wiggans, L. Ma, T. S. Sonstegard, T. J. Lawlor, B. A. Crooker, C. P. Van Tassell, J. Yang, S. Wang, L. K. Matukumalli, and Y. Da. 2011. Genome-wide association analysis of thirty-one production, health, reproduction and body conformation traits in contemporary U.S. Holstein cows. BMC Genomics 12:408. https://doi.org/10.1186/1471-2164-12-408.

Cruickshank, J., K. A. Weigel, M. R. Dentine, and B. W. Kirkpatrick. 2002. Indirect prediction of herd life in Guernsey dairy cattle. J. Dairy Sci. 85:1307-1313. https://doi.org/10.3168/jds.S0022 -0302(02)74195-7.

Cyrillo, J. N. S. G., A. G. Razook, L. A. de Figueiredo, L. M. Bonilha Neto, M. E. Z. Mercadante, and H. Tonhati. 2001. Estimativas de tendências e parâmetros genéticos do peso padronizado aos 378 dias de idade, medidas corporais e perímetro escrotal de machos Nelore de Sertãozinho, SP. Rev. Bras. Zootec. 30:56-65. https:// doi.org/10.1590/S1516-35982001000100010.

de Camargo, G. M. F., R. R. Aspilcueta-Borquis, M. R. S. Fortes, R. Porto-Neto, D. F. Cardoso, D. J. A. Santos, S. A. Lehnert, A. Reverter, S. S. Moore, and H. Tonhati. 2015. Prospecting major genes in dairy buffaloes. BMC Genomics 16:872. https://doi.org/ 10.1186/s12864-015-1986-2.

Deng, T., A. Liang, S. Liang, X. Ma, X. Lu, A. Duan, C. Pang, G. Hua, S. Liu, G. Campanile, A. Salzano, B. Gasparrini, G. Neglia, X. Liang, and L. Yang. 2019. Integrative analysis of transcriptome and GWAS data to identify the hub genes associated with milk yield trait in buffalo. Front. Genet. 10:36. https://doi.org/10 .3389/fgene.2019.00036.

El-Halawany, N., H. Abdel-Shafy, A. E. M. A. Shawky, M. A. Abdel-Latif, A. F. M. Al-Tohamy, and O. M. A. El-Moneim. 2017. Genome-wide association study for milk production in Egyptian buffalo. Livest. Sci. 198:10-16. https://doi.org/10.1016/j.livsci .2017.01.019.

FAO (Food and Agriculture Organization of the United Nations). 2017. FAOSTAT: Live animals. Accessed Jan. 29, 2019. http:// www.fao.org/faostat/en/\#data/QA.

Formigoni, I. B., J. B. S. Ferraz, J. A. I. V. Silva, J. P. Eler, and R. C. Brumatti. 2005. Valores econômicos para habilidade de permanên- cia e probabilidade de prenhez aos 14 meses em bovinos de corte. Arq. Bras. Med. Vet. Zootec. 57(Suppl. 2):220-226. https://doi .org/10.1590/S0102-09352005000800013.

Fragomeni, B. O., I. Misztal, D. L. Lourenco, I. Aguilar, R. Okimoto, and W. M. Muir. 2014. Changes in variance explained by top SNP windows over generations for three traits in broiler chicken. Front. Genet. 5:332. https://doi.org/10.3389/fgene.2014.00332.

Frazer, K. A., S. S. Murray, N. J. Schork, and E. J. Topol. 2009. Human genetic variation and its contribution to complex traits. Nat. Rev. Genet. 10:241-251. https://doi.org/10.1038/nrg2554.

Hagger, C., and A. Hofer. 1991. Phenotypic and genetic relationships between wither height, heart girth and milk yield in the Swiss Braunvieh and Simmental breeds. Livest. Prod. Sci. 28:265-271. https://doi.org/10.1016/0301-6226(91)90147-I.

Heidelberger, P., and P. D. Welch. 1983. Simulation run length control in the presence of an initial transient. Oper. Res. 31:1109-1144. https://doi.org/10.1287/opre.31.6.1109.

Hirschhorn, J. N., and M. J. Daly. 2005. Genome-wide association studies for common diseases and complex traits. Nat. Rev. Genet. 6:95-108. https://doi.org/10.1038/nrg1521.

Kinsella, R. J., A. Kähäri, S. Haider, J. Zamora, G. Proctor, G. Spudich, J. Almeida-King, D. Staines, P. Derwent, A. Kerhornou, P. Kersey, and P. Flicek. 2011. Ensembl BioMarts: A hub for data retrieval across taxonomic space. Database (Oxford) 2011:bar030. https://doi.org/10.1093/database/bar030.

Lagrotta, M. R., R. F. Euclydes, R. S. Verneque, M. L. Santana Júnior, R. J. Pereira, and R. A. Torres. 2010. Relação entre características morfológicas e produ ção de leite em vacas da raça Gir. Pesqui. Agropecu. Bras. 45:423-429. https://doi.org/10.1590/ S0100-204X2010000400011.

Liu, J. J., A. X. Liang, G. Campanile, G. Plastow, C. Zhang, Z. Wang, A. Salzano, and B. Gasparrini. 2018. Genome-wide association studies to identify quantitative trait loci affecting milk production traits in water buffalo. J. Dairy Sci. 101:433-444. https://doi.org/ $10.3168 /$ jds.2017-13246.

Ma, L., G. R. Wiggans, S. Wang, T. S. Sonstegard, J. Yang, B. A. Crooker, J. B. Cole, C. P. Van Tassell, T. J. Lawlor, and Y. Da. 2012. Effect of sample stratification on dairy GWAS results. BMC Genomics 13:536. https://doi.org/10.1186/1471-2164-13-536.

Mao, X., G. Sahana, D. J. De Koning, and B. Guldbrandtsen. 2016. Genome-wide association studies of growth traits in three dairy cattle breeds using whole-genome sequence data. J. Anim. Sci. 94:1426-1437. https://doi.org/10.2527/jas.2015-9838.

Meredith, B. K., F. J. Kearney, E. K. Finlay, D. G. Bradley, A. G. Fahey, D. P. Berry, and D. J. Lynn. 2012. Genome-wide associations for milk production and somatic cell score in HolsteinFriesian cattle in Ireland. BMC Genet. 13:21. https://doi.org/10 .1186/1471-2156-13-21.

Michelizzi, V. N., M. V. Dodson, Z. Pan, M. E. J. Amaral, J. J. Michal, D. J. McLean, J. E. Womack, and Z. Jiang. 2010. Water buffalo genome science comes of age. Int. J. Biol. Sci. 6:333-349. https://doi.org/10.7150/ijbs.6.333.

Michenet, A., M. Barbat, R. Saintilan, E. Venot, and F. Phocas. 2016. Detection of quantitative trait loci for maternal traits using highdensity genotypes of Blonde d'Aquitaine beef cattle. BMC Genet. 17:88. https://doi.org/10.1186/s12863-016-0397-y.

Misztal, I. 2007. BLUPF90 family of programs. Accessed May 25, 2019. http://nce.ads.uga.edu/ ignacy/newprograms.html.

Misztal, I., S. Tsuruta, D. Lourenço, and Y. Masuda. 2002. BLUPF90 family of programs. Accessed Nov. 30, 2018. http://nce.ads.uga .edu/ ignacy/numpub/blupf90/.

Mokhber, M., M. Moradi-Shahrbabak, M. Sadeghi, H. Moradi-Shahrbabak, A. Stella, E. Nicolzzi, J. Rahmaninia, and J. L. Williams. 2018. A genome-wide scan for signatures of selection in Azeri and Khuzestani buffalo breeds. BMC Genomics 19:449. https://doi .org/10.1186/s12864-018-4759-x.

National Animal Genome Research Program. 2018. CattleQTLdb. Accessed Oct. 16, 2018. https://www.animalgenome.org/cgi-bin/ QTLdb/BT/index.

Peñagaricano, F., K. A. Weigel, G. J. M. Rosa, and H. Khatib. 2013. Inferring quantitative trait pathways associated with bull fertility 
from a genome-wide association study. Front. Genet. 3:307. https: //doi.org/10.3389/fgene.2012.00307.

Peters, S. O., K. Kizilkaya, D. J. Garrick, R. L. Fernando, J. M. Reecy, R. L. Weaber, G. A. Silver, and M. G. Thomas. 2012. Bayesian genome-wide association analysis of growth and yearling ultrasound measures of carcass traits in Brangus heifers. J. Amin. Sci. 90:3398-3409. https://doi.org/10.2527/jas.2011-4507.

Sewalem, A., F. Miglior, and G. J. Kistemaker. 2010. Analysis of the relationship between workability traits and functional longevity in Canadian dairy breeds. J. Dairy Sci. 93:4359-4365. https://doi .org/10.3168/jds.2009-2969.

Smith, B. J. 2007. BOA: An R package for MCMC output convergence assessment and posterior inference. J. Stat. Softw. 21:11. https:// doi.org/10.18637/jss.v021.i11.

Snelling, W. M., M. F. Allan, J. W. Keele, L. A. Kuehn, T. McDaneld, T. P. Smith, T. S. Sonstegard, R. M. Thallman, and G. L. Bennett. 2010. Genome-wide association study of growth in crossbred beef cattle. J. Anim. Sci. 88:837-848. https://doi.org/10.2527/jas $.2009-2257$

Sun, X. D. Habier, R. L. Fernando, D. J. Garrick, and J. C. M. Dekkers. 2011. Genomic breeding value prediction and QTL mapping of QTLMAS2010 data using Bayesian methods. BMC Proc. 5(Suppl. 3):S13. https://doi.org/10.1186/1753-6561-5-S3-S13.

Tiezzi, F., K. L. Parker-Gaddis, J. B. Cole, J. S. Clay, and C. Maltecca. 2015. A genome-wide association study for clinical mastitis in first parity US Holstein cows using single-step approach and genomic matrix re-weighting procedure. PLoS One 10:e0114919. https://doi.org/10.1371/journal.pone.0114919.

Tonhati, H., M. F. M. Céron, J. A. Oliveira, J. M. C. Duarte, T. P. Furtado, and S. P. Tseimazides. 2000a. Parâmetros genéticos para a produção de leite, gordura e proteína em bubalinos. Rev. Bras. Zootec. 29:2051-2056.

Tonhati, H., F. B. Vasconcellos, and L. G. Albuquerque. 2000b. Genetic aspects of productive and reproductive traits in a Murrah buffalo herd in São Paulo, Brazil. J. Anim. Breed. Genet. 117:331336. https://doi.org/10.1046/j.1439-0388.2000.00249.x.

VanRaden, P. M. 2008. Efficient methods to compute genomic predictions. J. Dairy Sci. 91:4414-4423. https://doi.org/10.3168/jds .2007-0980.

Verneque, R., M. G. C. D. Peixoto, A. E. Vercesi Filho, M. A. Machado, M. V. G. B. da Silva, A. R. Fernandes, and C. H. C. Machado. 2008. Programa nacional de melhoramento do Gir leiteiro-
Sumário brasileiro de touros-Resultado do teste de progênie. Embrapa Gado de Leite, Juiz de Fora, MG, Brazil.

Wang, H., I. Misztal, I. Aguilar, A. Legarra, R. L. Fernando, Z. Vitezica, R. Okimoto, T. Wing, R. Hawken, and W. M. Muir. 2014. Genome-wide association mapping including phenotypes from relatives without genotypes in a single-step (ssGWAS) for 6-week body weight in broiler chickens. Front. Genet. 5:134. https://doi .org/10.3389/fgene.2014.00134

Wang, H., I. Misztal, I. Aguilar, A. Legarra, and W. M. Muir. 2012. Genome-wide association mapping including phenotypes from relatives without genotypes. Genet. Res. (Camb.) 94:73-83. https:// doi.org/10.1017/S0016672312000274.

Warriach, H. M., D. M. McGill, R. D. Bush, P. C. Wynn, and K. R. Chohan. 2015. A review of recent developments in buffalo reproduction-A review. Asian-australas. J. Anim. Sci. 28:451-455. https://doi.org/10.5713/ajas.14.0259.

Wenceslau, A. A., P. S. Lopes, R. L. Teodoro, S. Verneque, R. F. Euclydes, W. J. Ferreira, and M. De Almeida. 2000. Estimação de parâmetros genéticos de medidas de conformação, produção de leite e idade ao primeiro parto em vacas da raça Gir Leiteiro. Ver. Bras. Zootec. 29:153-158.

Yamazaki, S., R. Iwamoto, K. Saeki, M. Asakura, S. Takashima, A. Yamazaki, R. Kimura, H. Mizushima, H. Moribe, S. Higashiyama, M. Endoh, Y. Kaneda, S. Takagi, S. Itami, N. Takeda, G. Yamada, and E. Mekada. 2003. Mice with defects in HB-EGF ectodomain shedding show severe developmental abnormalities. J. Cell Biol. 163:469-475. https://doi.org/10.1083/jcb.200307035.

Zaborski, D., W. Grzesiak, and R. Pilarczyk. 2016. Detection of difficult calvings in the Polish Holstein-Friesian Black-and-White heifers. J. Appl. Anim. Res. 44:42-53. https://doi.org/10.1080/ 09712119.2014.987293.

Zhang, Z., J. Liu, X. Ding, P. Bijma, D. J. de Koning, and Q. Zhang. 2010. Best linear unbiased prediction of genomic breeding values using a trait-specific marker-derived relationship matrix. PLoS One 5:e12648. https://doi.org/10.1371/journal.pone.0012648.

Zimin, A. V., A. L. Delcher, L. Florea, D. R. Kelley, M. C. Schatz, D. Puiu, F. Hanrahan, G. Pertea, C. P. Van Tassell, T. S. Sonstegard, G. Marçais, M. Roberts, P. Subramanian, J. A. Yorke, and S. L. Salzberg. 2009. A whole-genome assembly of the domestic cow, Bos taurus. Genome Biol. 10:R42. https://doi.org/10.1186/ gb-2009-10-4-r42. 